\title{
STUDIES OF COLON CONTRACTILITY IN DOGS. I. DESCRIPTION OF METHOD AND EFFECT OF PARASYMPATHOMIMETIC AGENTS AND SEROTONIN * $\dagger$
}

\author{
By MARVIN H. SLEISENGER, DAVID H. LAW, FREDERICK W. SMITH, \\ JAMES H. PERT $\ddagger$ AND CHARLES M. LEWIS § \\ (From the Department of Medicine, New York Hospital-Cornell Medical Center, \\ New York, N. Y.)
}

(Submitted for publication June 2, 1959; accepted August 7, 1959)

The effects of autonomic substances and 5-hydroxytryptamine (serotonin) upon the smooth muscle of the intestine are not completely understood despite extensive experimentation in vitro and in vivo. Serotonin may play an important role in the normal regulation of intestinal motility, since, in vitro, it causes strong contraction of intestinal smooth muscle $(1,2)$; when given intravenously both to man and certain experimental animals, it stimulates intestinal motility (3-5); and its excess production is associated with diarrhea and increased peristalsis in the metastatic carcinoid syndrome $(6,7)$. The major body depot of serotonin is the gastrointestinal tract where it is localized in the enterochromaffin cells of the $\mathrm{mu}$ cosa. Its mechanism of action upon the intestine is unclear, and there are many conflicting reports on its relationship to the autonomic nervous system $(1-5,8-10)$.

In order more closely to ascertain the effect of acetylcholine, methacholine and serotonin upon mammalian intestinal smooth muscle, an in vivo experimental technique has been devised. This method, which is easy to perform and yields reproducible results, makes it possible to introduce the test substances directly and initially into the intact intestine. This is accomplished by injections into the terminal or end artery, which nourishes a segment of proximal colon, of an anesthetized dog.

* This work was supported by a Grant-in-Aid from the National Institute of Arthritis and Metabolic Diseases, National Institutes of Health, United States Public Health Service.

$\dagger$ Presented in part before the combined section meeting of the American Society for Clinical Investigation and the American Federation for Clinical Research in Atlantic City, N. J., May, 1958.

$\ddagger$ Present address: American National Red Cross, National Headquarters, Washington, D. C.

$\S$ Present address: 600 Broadway, Paterson, N. J.
The purpose of the present report is to describe the method, to detail the effect of lowering tissue cholinesterase upon the action of parasympathomimetic agents, and to help clarify the mechanism of action of serotonin, with particular reference to the parasympathetic nervous system.

\section{METHODS AND MATERIALS}

Mongrel dogs weighing 10 to $20 \mathrm{Kg}$. were used in all experiments. The animals were fasted for 48 hours prior to the study to insure an empty gastrointestinal tract. Intraperitoneal injection of $0.5 \mathrm{ml}$. per $\mathrm{Kg}$. Dial ${ }^{\circledR}$ with Urethane 1 induced a surgical plane of anesthesia within 15 minutes, which was maintained for eight to 10 hours. An endotracheal tube was inserted and attached to a positive pressure oxygen breathing apparatus in order to insure adequate oxygenation. A constant intravenous drip of 5 per cent glucose solution was given slowly throughout. Although aseptic surgical technique was not employed, the operators wore rubber gloves during the preparation of the specimen and maintained a clean and relatively bloodless field. Following a midline or right rectus incision, the mesenteric arterial blood supply to the proximal 7 to $12 \mathrm{~cm}$. of colon was isolated. A distal branch of the artery was injected with $1.0 \mu \mathrm{g}$. of acetylcholine, and the segment of proximal colon in which spasm occurred was marked and then intubated with a rubber catheter which was passed through the terminal ileum and ileocaecal valve into the segment. The distal end of this catheter was attached to a small latex balloon approximating the size of the bowel lumen but not distending it. Balloon, catheter, and an attached manometer were all filled with water, and this system was connected by air-filled tubing to a writing arm which recorded contractions kymographically (Figure 1). Throughout all experiments the exposed loop of gut was kept moistened with warm Locke's solution.

To facilitate injections into the end artery, a short length of silk was passed under the vessel so that it could

${ }^{1}$ Generously supplied by Dr. Robert R. Smith, Ciba Pharmaceutical Products, Summit, N. J. Dial@-Urethane contains diallyl-barbituric acid, 10 per cent; Urethane, 40 per cent; monoethylurea, 40 per cent; water, 10 per cent. 


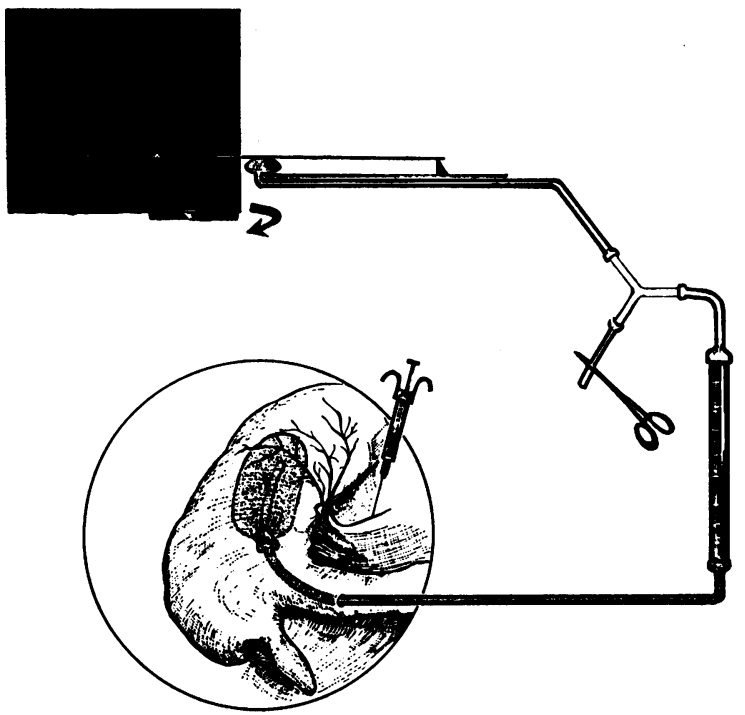

Fig. 1. Diagram of the Intubated Segment with Isolated Terminal Artery into which Test Agents ARE INJECTED

Balloon, catheter and variable length of manometer only are water filled.

be stabilized by exerting tension prior to each injection. All injections were made with a $1 \mathrm{ml}$. syringe and a 27 gauge needle (Figure 1). Injections were noted on the recording drum by means of an electric signal marker or manual compression of the rubber tubing leading from the manometer. Unless otherwise specified, all test substances ${ }^{2}$ were injected in volumes of $0.1 \mathrm{ml}$.

${ }^{2}$ Serotonin kindly provided as Serotonin Creatinine Sulfate by Dr. D. A. Sheperd, Upjohn Company, Kalamazoo, Mich.

DOG no.7
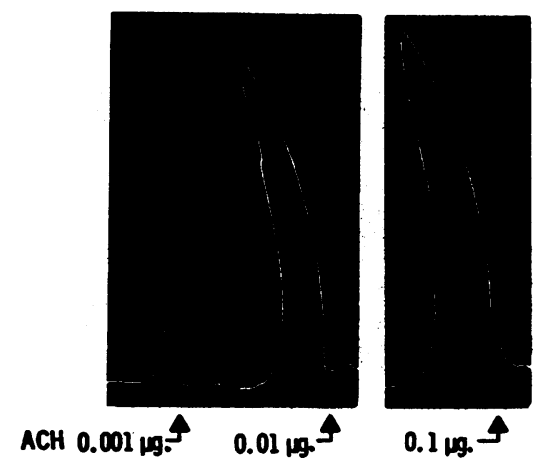

as rapidly as possible, each injection averaging one second. All test solutions were freshly prepared for each experiment and dissolved in Locke's solution containing bicarbonate. ${ }^{3}$ The $\mathrm{pH}$ of this solution ranged from 7.5 to 7.7. Injection of this solution was without effect upon the intestine.

Great care was exercised during the preparation of the di-isopropylfluorophosphate (DFP) solution. ${ }^{4}$ The material was always handled under a hood, the experimenter's arms extending through aperatures in its window. One-tenth gram DFP $(0.1 \mathrm{ml}$.) was carefully withdrawn from the stock container, placed in a 100 $\mathrm{ml}$. volumetric flask, and diluted with buffered Locke's solution, yielding a final concentration of $1.0 \mathrm{mg}$. per $\mathrm{ml}$. The container was then carefully sealed and immersed in a metal can of sodium bicarbonate. All DFP injections were given within one-half hour of preparation.

Cholinesterase determinations were performed on segments of colon in a number of experiments. Since the test segment of colon could not be used as its own control for cholinesterase content, a segment distal to it was also removed at the end of some experiments in which DFP had been given. Cholinesterase values for these two sections of colon were comparable under normal circumstances. Determinations of tissue cholinesterase in these segments were performed by the Warburg manometric technique with acetylcholine as substrate (11). The average of three 10 minute incubations was chosen as the final value, and the results were expressed as microliters of $\mathrm{CO}_{2}$ per $0.1 \mathrm{Gm}$. tissue. Control determinations in 30 animals revealed that the normal cholinesterase value varied between 65 and $125 \mu 1 . \mathrm{CO}_{2}$ per 0.1 $\mathrm{Gm}$. tissue, with an average of 100 . All determinations were performed immediately or after freezing (11).

${ }^{3}$ One L. Locke's solution to $2.1 \mathrm{Gm}$. sodium bicarbonate.

4 Kindly provided by Dr. Bernard J. Jandorf, Army Chemical Center, Md.

DOG no. 3

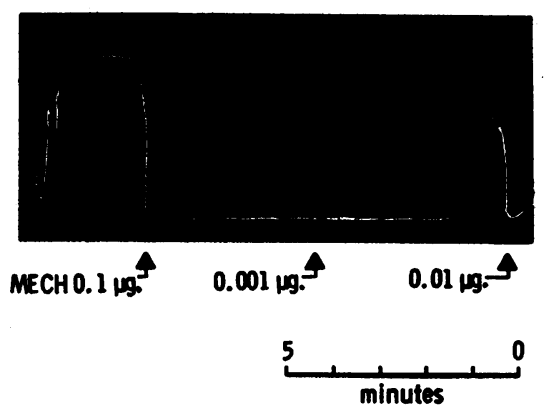

Fig. 2. Dose Response

Note characteristic responses for acetylcholine $(\mathrm{ACH})$ and methacholine $(\mathrm{MECH})$. Read right to left. 


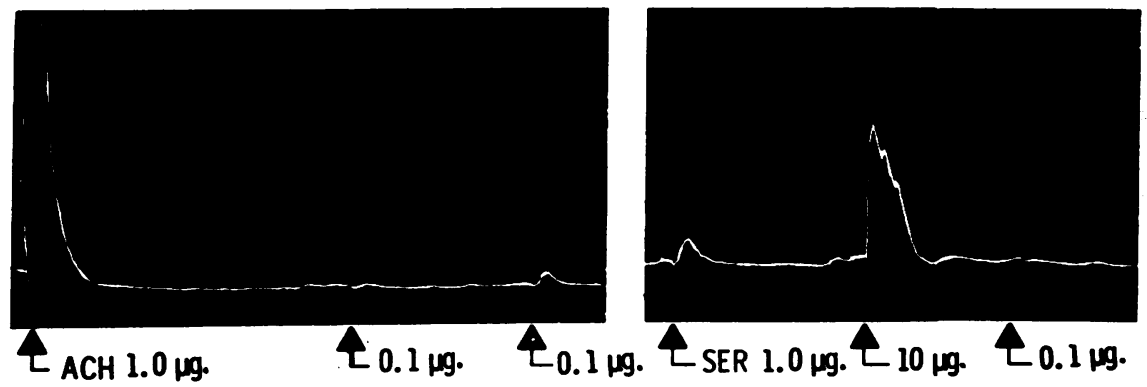

Fig. 3. Comparison of Acetylcholine (ACH) and Serotonin Responses

Note that character of relaxation of serotonin (SER) differs from that following $\mathrm{ACH}$ and is irregular. Read left to right.

In discussing our results, we define any decrease in threshold dose of a test substance (decrease in dosage level required to produce a discrete contraction of the bowel) as potentiation, whereas a heightened and/or prolonged response at the same dosage level is termed augmentation.

In all experiments, there was little or no baseline activity, and threshold responses were easily identified and always reproducible in the same animal.

\section{RESULTS}

\section{Effects of acetylcholine, methacholine and serotonin}

In 30 experiments the amount of acetylcholine required to produce minimal discrete contractions averaged $0.01 \mu \mathrm{g}$. (range, 0.001 to $0.1 \mu \mathrm{g}$.), and in 15 animals the mean threshold dose for methacholine was $0.1 \mu \mathrm{g}$. (range, 0.001 to $1.0 \mu \mathrm{g}$.).

While the ratio for the average threshold doses of acetylcholine/methacholine was $10 / 1$, this relationship varied considerably and unpredictably in the individual experiment. A characteristic response was noted for each of these substances, contractions caused by acetylcholine being of shorter duration than those caused by methacholine. In 26 animals, serotonin caused a vigorous intestinal contraction with the average threshold dose of $0.01 \mu \mathrm{g}$. (range 0.001 to $1.0 \mu \mathrm{g}$.). While the mean threshold dose of serotonin was the same as that for acetylcholine, the character of the curve of relaxation differed slightly from that of acetylcholine. The response curves for each of these substances are shown in Figures 2 and 3.

\section{Effect of inhibition of colon cholinesterase by DFP}

Tissue cholinesterase in the intubated segment was abruptly reduced following intra-arterial injection of DFP. Amounts of this drug in excess of $50 \mu \mathrm{g}$. per $\mathrm{Kg}$. could not be used because they induced prolonged colonic spasm which prevented retesting for several hours. Although spasm was noted following administration of 25 to $50 \mu \mathrm{g}$. per $\mathrm{Kg}$. intra-arterially (Figure 4 ), repeat injections invariably could be carried out within an

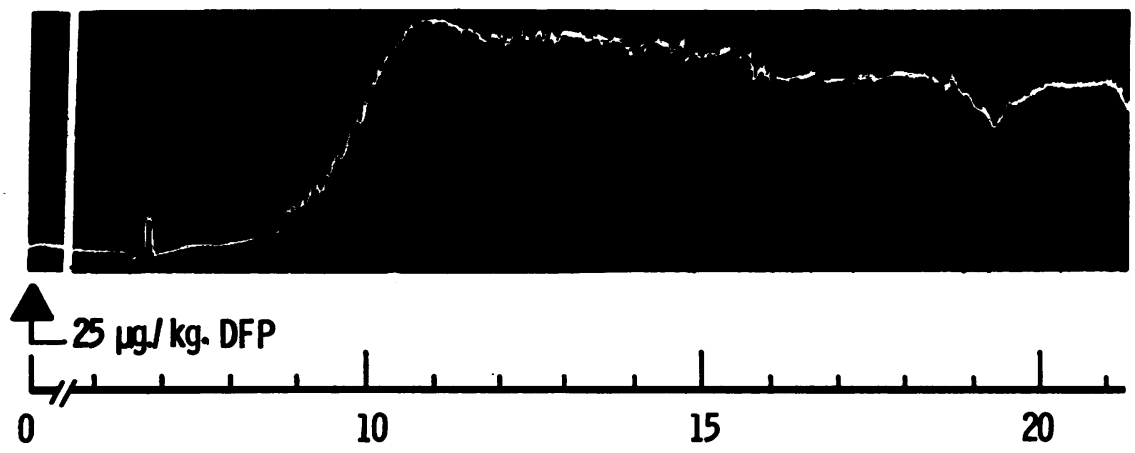

Fig. 4. EFFeCt of Di-ISOPROPYlfluorophosphate (DFP) on Motility

Duration of this spasm induced by intra-arterial injections of $25.0 \mu \mathrm{g}$. per $\mathrm{Kg}$. DFP was 30 minutes, after which test substances could be administered. Read left to right. 
TABLE I

Effect of inhibition of colon cholinesterase (CHE) on response to acetylcholine $(A)$, methacholine $(M)$

\begin{tabular}{|c|c|c|c|c|c|c|}
\hline Dog & Drug & $\begin{array}{l}\text { Control } \\
\text { threshold } \\
\text { dose }\end{array}$ & DFP* & $\begin{array}{l}\text { Post-DFP } \\
\text { threshold }\end{array}$ & $\underset{\substack{\text { Aug- } \\
\text { menta- } \\
\text { tion }}}{\text {. }}$ & $\begin{array}{c}\text { Inhibi- } \\
\text { tion } \\
\text { colon } \\
\text { (CHE) }\end{array}$ \\
\hline $\begin{array}{r}\text { No. } \\
4\end{array}$ & $\begin{array}{l}\text { A } \\
\mathbf{M}\end{array}$ & $\begin{array}{l}\mu g . \\
0.1 \\
0.01\end{array}$ & $\begin{array}{c}\mu \mathrm{g} . / \mathrm{Kg} \\
50\end{array}$ & $\begin{array}{l}\mu g . \\
0.0001 \\
0.01\end{array}$ & $\begin{array}{l}+ \\
+\end{array}$ & $\begin{array}{c}\% \\
91 \dagger\end{array}$ \\
\hline 7 & $\begin{array}{l}\text { A } \\
\mathbf{M}\end{array}$ & $\begin{array}{l}0.1 \\
0.1\end{array}$ & 50 & 0.1 & $\begin{array}{l}+ \\
+\end{array}$ & $90 \dagger$ \\
\hline 8 & $\begin{array}{l}\text { A } \\
\mathbf{M}\end{array}$ & $\begin{array}{l}0.1 \\
1.0\end{array}$ & 50 & $\begin{array}{l}0.01 \\
0.1\end{array}$ & $\begin{array}{l}+ \\
+\end{array}$ & $80 \dagger$ \\
\hline 9 & $\begin{array}{l}\mathbf{A} \\
\mathbf{M}\end{array}$ & $\begin{array}{l}0.01 \\
0.001\end{array}$ & 50 & $\begin{array}{l}0.1 \\
0.01\end{array}$ & $\begin{array}{l}+ \\
+\end{array}$ & $50 \dagger$ \\
\hline 14 & $\begin{array}{l}\text { A } \\
M\end{array}$ & $\begin{array}{l}0.1 \\
1.0\end{array}$ & 50 & 0.1 & $\begin{array}{l}+ \\
+\end{array}$ & 67 \\
\hline 15 & $\begin{array}{l}\text { A } \\
\mathbf{M}\end{array}$ & $\begin{array}{l}0.5 \\
0.1\end{array}$ & 25 & $\begin{array}{l}0.01 \\
0.1\end{array}$ & $\begin{array}{l}+ \\
+\end{array}$ & 87 \\
\hline 17 & $\begin{array}{l}\mathbf{A} \\
\mathbf{M}\end{array}$ & $\begin{array}{l}0.05 \\
0.1\end{array}$ & 12.5 & $\begin{array}{l}0.5 \\
0.5\end{array}$ & $\begin{array}{l}+ \\
+\end{array}$ & $43 t$ \\
\hline 18 & $\begin{array}{l}\mathbf{A} \\
\mathbf{M}\end{array}$ & $\begin{array}{l}0.05 \\
0.01\end{array}$ & 25 & $\begin{array}{l}0.05 \\
0.01\end{array}$ & $\begin{array}{l}+ \\
+\end{array}$ & 75 \\
\hline 19 & $\begin{array}{l}\mathrm{A} \\
\mathrm{M}\end{array}$ & $\begin{array}{l}0.5 \\
0.1\end{array}$ & 25 & $\begin{array}{l}0.01 \\
0.1\end{array}$ & $\begin{array}{l}+ \\
+\end{array}$ & 88 \\
\hline 47 & A & 0.5 & 25 & 0.1 & + & 94 \\
\hline
\end{tabular}

* Di-isopropylfluorophosphate.

$\dagger$ Values are in reference to the mean cholinesterase concentrations of the colons of 30 control dogs (11). hour. In Table I are the results of retesting the colonic segment with acetylcholine and methacholine following the injections of DFP in the range of 12.5 to $50.0 \mu \mathrm{g}$. per $\mathrm{Kg}$. In five animals the percentage of cholinesterase inhibition is based on the ratio of cholinesterase in the test segment following DFP to that of a segment of distal colon removed at the end of the experiment. In five other animals, the ratio was in reference to the average of a control series of 30 dogs (11). It will be noted that in all instances augmentation of response was obtained (Figure 5). It is of special interest that potentiation of acetylcholine, i.e., lowering of the threshold, occurred in only five animals (Nos. 4, 8, 15, 19, 47) and in all of these the inhibition of colon cholinesterase was 80 per cent or more. In the remaining animals (Nos. 7, $9,14,17,18)$ in which potentiation of acetylcholine did not occur, cholinesterase inhibition was less than 80 per cent, except for Dog No. 7 in which it was 90 per cent. In only one experiment (Dog No. 8) did potentiation of methacholine occur.

To determine the relationship of serotonin response to the cholinergic nervous system, the com-

CONTROL
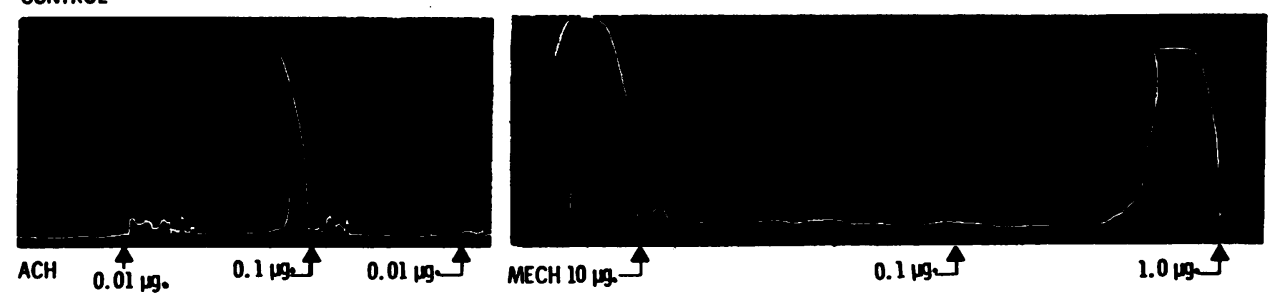

150 minutes after DFP
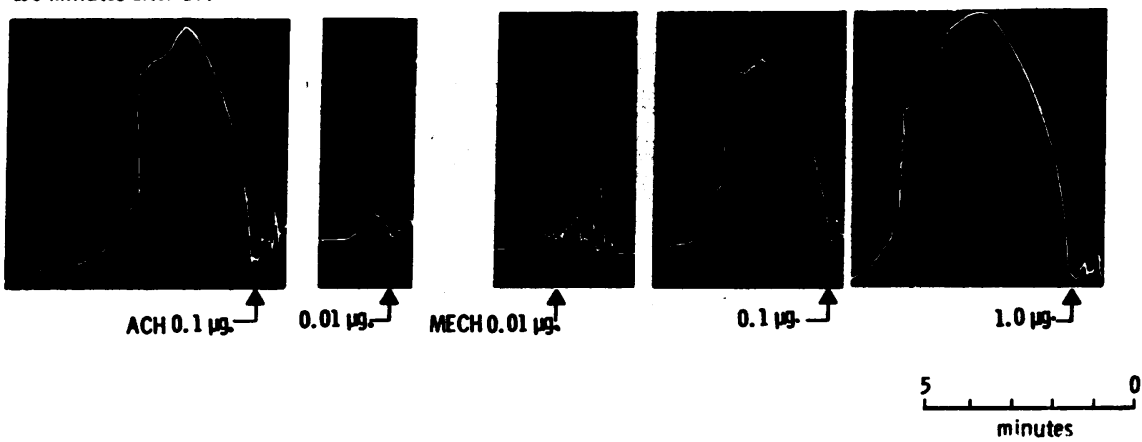

Fig. 5. Effect of Cholinesterase Depression on Acetylcholine (ACH) and MethaCholine (MECH) Response (Dog No. 8)

Effect of $\mathrm{ACH}$ and $\mathrm{MECH}$ before and after injection of di-isopropylfluorophosphate (DFP), $50 \mu \mathrm{g}$. per $\mathrm{Kg}$. Although tissue cholinesterase was inhibited 80 per cent, there was only 10 -fold decrease in threshold for each substance; however, marked augmentation is seen. Read right to left. 

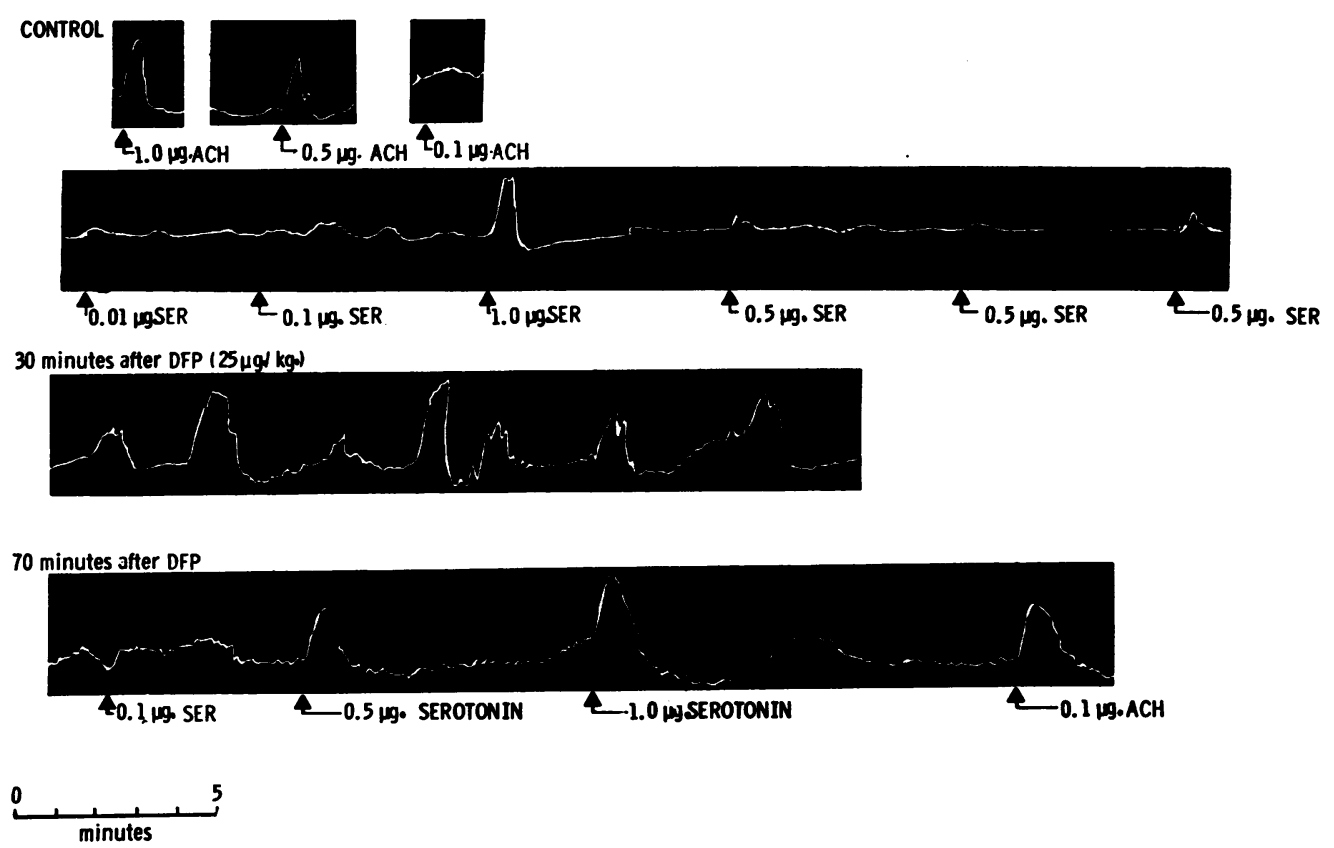

Fig. 6. Effect of Cholinesterase Depression on Acetylcholine (ACH) and Serotonin (SER) Response (Dog No. 47)

Augmentation of both $\mathrm{ACH}$ and SER responses followed intra-arterial injection of di-isopropylfluorophosphate (DFP), $25 \mu \mathrm{g}$. per $\mathrm{Kg}$. Change in threshold was noted also for $\mathrm{ACH}$. Colon cholinesterase was reduced 85 per cent. Read left to right.

parative effect of marked lowering of colon cholinesterase ( 75 to 95 per cent) upon the action of serotonin and acetylcholine was studied in two animals (Nos. 47, 49). The threshold for acetylcholine decreased in one animal, but was unchanged for serotonin. Further, although serotonin response was augmented, the degree of augmentation was less than that for acetylcholine (Figure 6) and may represent an addition of effect of this agent combined with endogenous acetylcholine.

\section{Combined action of serotonin and acetylcholine}

To ascertain whether serotonin and acetylcholine enhance each other's action, we compared the effects of a mixture of half of the volume of an approximately equi-effective dose of each agent, with that of each reference dose. In no case of such combined administration did augmentation occur. In 11 of 14 observations the effects were only additive. In three trials, moreover, the response to the combination was less than that of

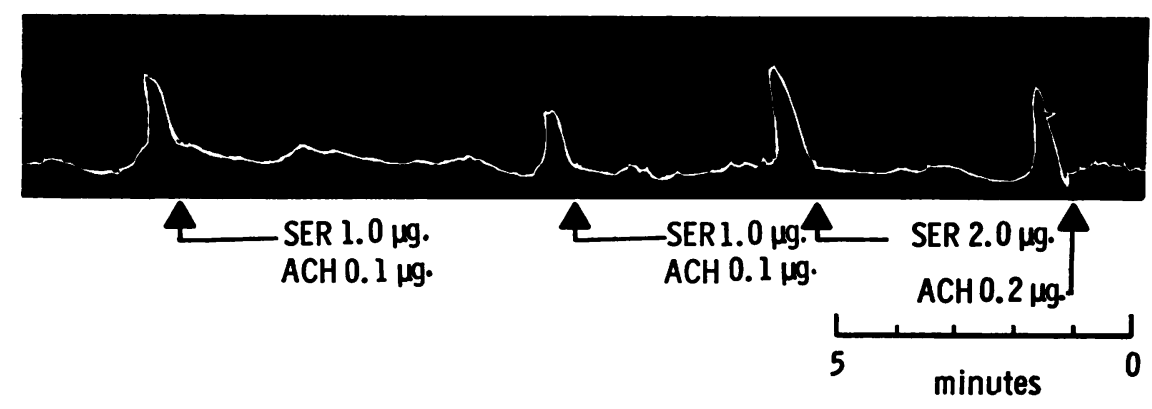

Fig. 7. Combined Acetylcholine (ACH) and Serotonin (SER) Action (Dog No. 45)

Augmentation did not result from mixture of half of an equi-effective dose of each agent, the response being merely additive on one occasion and diminished on another. Read right to left. 

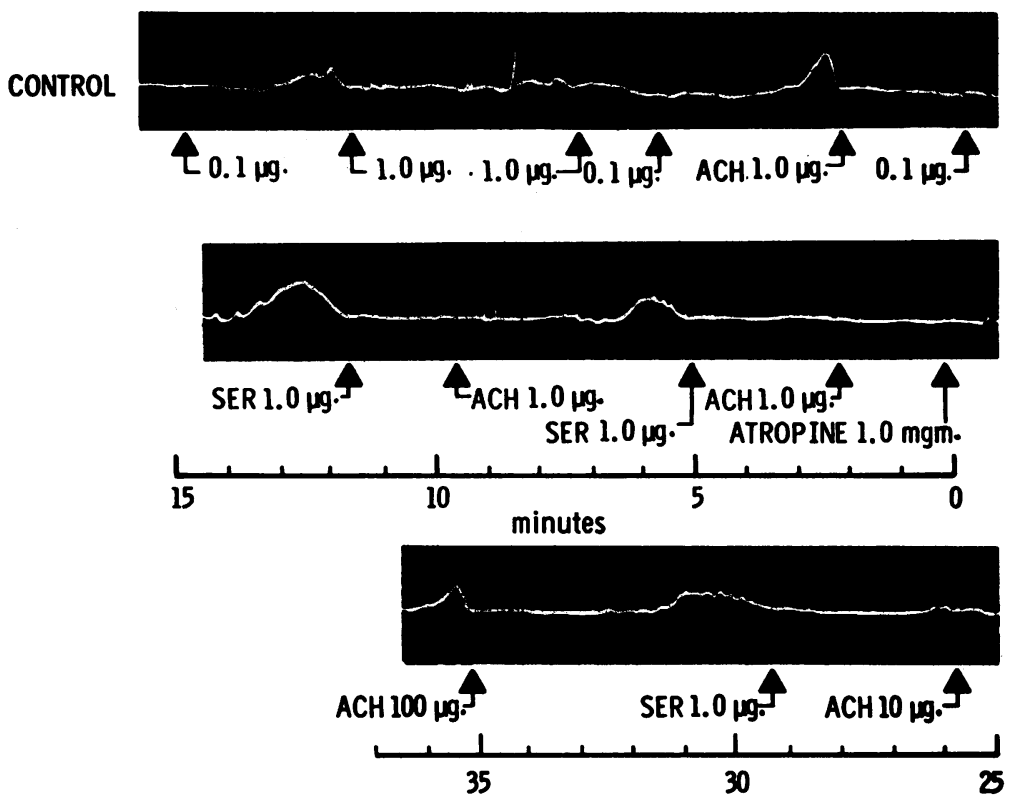

Fig. 8. Effect of Atropine (Dog No. 42)

Threshold dose for acetylcholine $(\mathrm{ACH})$ increased 100 times after $1.0 \mathrm{mg}$. atropine, although serotonin (SER) threshold dose was unchanged; response seemed to be enhanced. Read right to left.

either reference dose (Figure 7). In 25 dogs there was no alteration of response to acetylcholine administered from five seconds to 60 minutes after serotonin.

\section{Effect of an anticholinergic drug}

The effect of an anticholinergic agent, atropine, upon the action of serotonin was observed in eight animals. Figure 8 shows the effect of 1.0 $\mathrm{mg}$. of this substance on the subsequent injections of serotonin and acetylcholine. Although the threshold for acetylcholine was increased 100 -fold, the serotonin threshold was unaffected and indeed in several experiments there appeared to be augmentation (Figure 8). Higher doses of atropine, 6 to $8 \mathrm{mg}$., raised the serotonin threshold 10to 20-fold, while changing that for acetylcholine 1,000 - to 5,000 -fold. Even after 85 per cent inhibition of cholinesterase, the relative effectiveness of a large dose of atropine upon serotonin and acetylcholine was unchanged (Figure 9).

\section{Ganglion blockade}

Hexamethonium, 1.5 to $12.5 \mathrm{mg}$., did not block the action of either serotonin or acetylcholine; in- deed, in three of four observations, it seemed to augment the serotonin response (Figure 10).

\section{Monoamine oxidase inhibition}

$\mathrm{U}-7729,5$ a methyl analog of serotonin and monoamine oxidase inhibitor (MOI), was administered in doses of $100 \mu \mathrm{g}$. on nine occasions in four animals. On eight occasions it produced contraction of the bowel and it augmented the response of serotonin in five of nine instances and of acetylcholine on seven of nine occasions (Figure 11). In a fifth dog, no spontaneous response to the same dose of MOI was noted, although serotonin and acetylcholine contractions were augmented. Despite a total dose of $400 \mu \mathrm{g}$. MOI in each of four experiments, there was no alteration in the threshold dose for either drug.

Further, administration of MOI only slightly altered the relative effect of atropine upon serotonin and acetylcholine; i.e., the ratio of atropine inhibition of these agents (acetylcholine/serotonin) was between 10/1 and 100/1 (Figure 12).

5 Supplied by Dr. J. P. Webb, The Upjohn Company, Kalamazoo, Mich. 

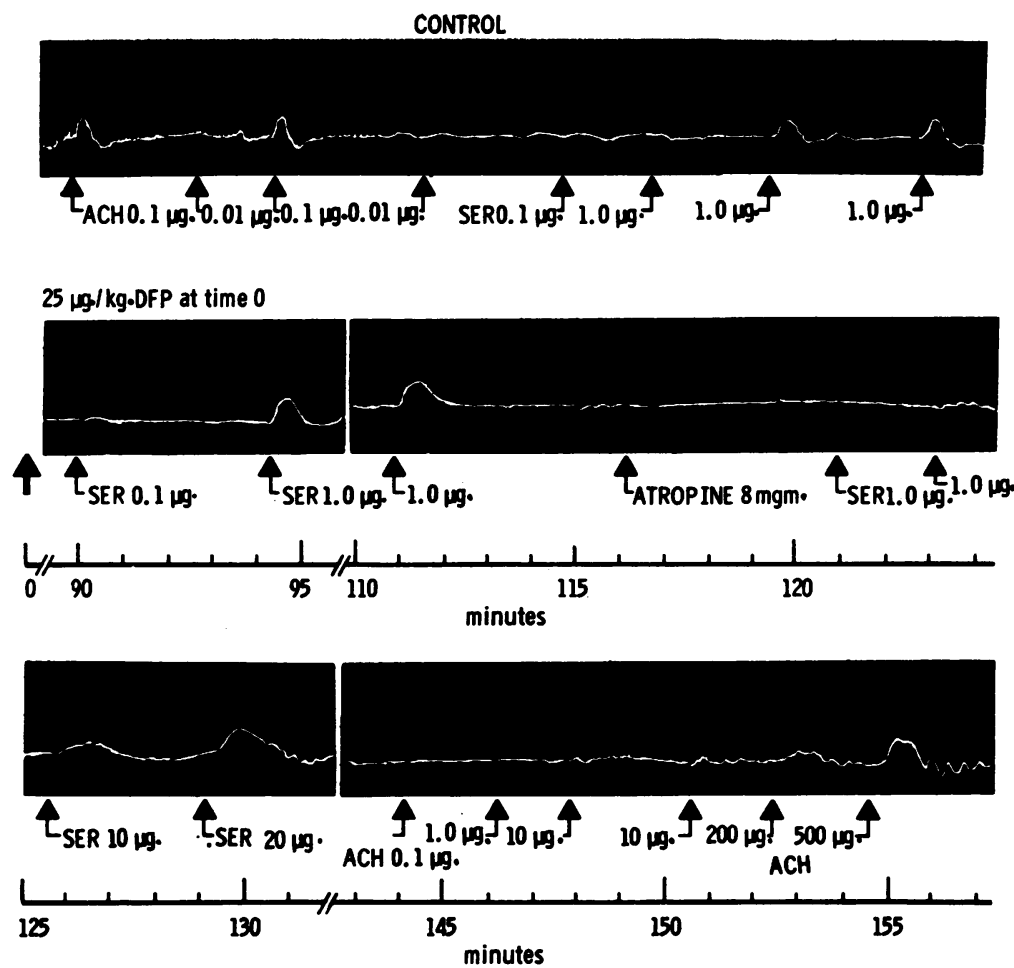

Fig. 9. EfFect of Di-isopropylfluorophosphate (DFP) on Atropine Blockade (Dog No. 49)

Depression of colon cholinesterase by DFP, $25 \mu \mathrm{g}$. per $\mathrm{Kg}$., did not alter the relative effectiveness of a massive dose of atropine, $8.0 \mathrm{mg}$., upon acetylcholine $(\mathrm{ACH})$ and serotonin (SER) responses. Colon cholinesterase was reduced 85 per cent. Read left to right.

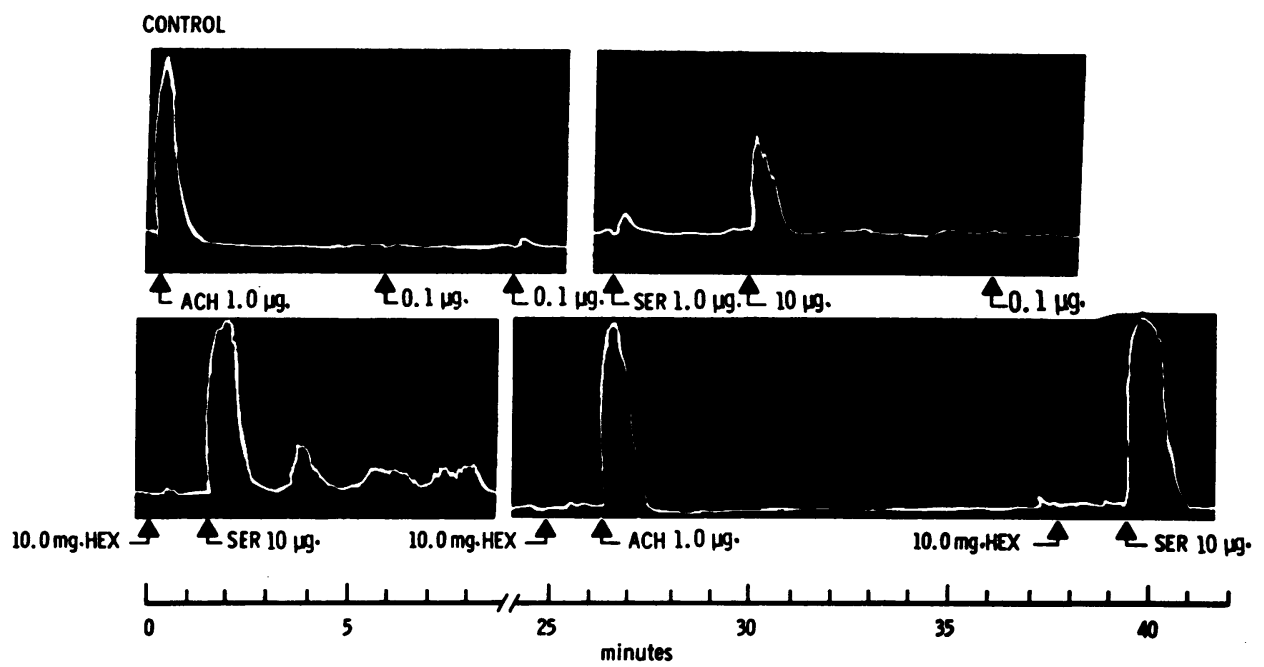

Fig. 10. Effect of Hexamethonium (Dog No. 52)

Three massive doses of hexamethonium, $10.0 \mathrm{mg}$. each, blocked neither acetylcholine (ACH) nor serotonin (SER). Effect of serotonin appeared to be augmented. Read left to right. 


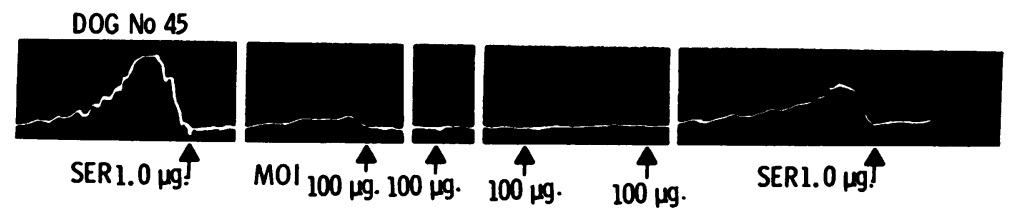

DOG No61

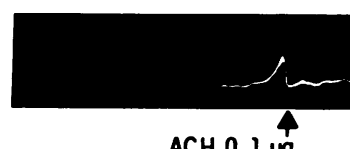

$\mathrm{ACH}, 0.1 \stackrel{\mathbf{p g}}{\text {. }}$

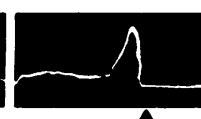

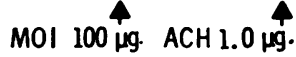
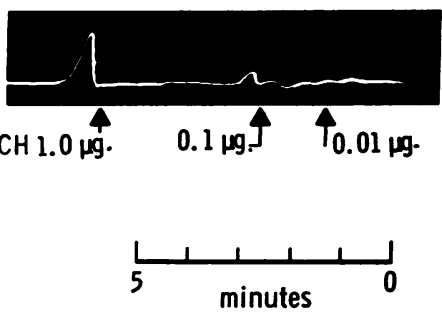

Fig. 11. Effect of Monoamine Oxidase Inhibitor (MOI)

In Dog No. 45, four injections of $100 \mu \mathrm{g}$. MOI, U-7729, augmented the response to serotonin (SER). In Dog No. 61, $100 \mu \mathrm{g}$. MOI induced a contraction and augmented acetylcholine $(\mathrm{ACH})$ response. Read right to left.

\section{Antiserotonin drugs}

Prochlorperazine (Compazine ${ }^{\circledR}$ ) in doses of $100 \mu \mathrm{g}$. inhibited the action of serotonin markedly in three observations, but did not alter acetylcholine effect (Figure 13). The benzyl analog of serotonin (BAS), provided by Dr. D. W. Wooley, effected a graded inhibition of serotonin response in a dose range of 1.0 to $4.0 \mathrm{mg}$. After $1.0 \mathrm{mg}$. there was a 10 -fold increase in serotonin threshold (Figure 14); after $4.0 \mathrm{mg}$., a 100 -fold increase, the duration of inhibitory effect averaging about 30 minutes. When $100 \mathrm{mg}$. of BAS was given intravenously on two occasions, there occurred a 10 -fold increase in threshold in one animal, but threshold was unaffected in the other. Neither prochlorperazine nor BAS changed the intestinal response to acetylcholine.

\section{DISCUSSION}

These studies on the effect of acetylcholine, methacholine and serotonin on the dog colon have demonstrated the advantages and usefulness of an in vivo intra-arterial injection technique. The procedure is simple, yields reproducible results and is stable enough to permit experimentation over an eight to 10 hour period. In addition, it permits recording intestinal action in a preparation that has an intact innervation and blood supply.

The contractile effect of acetylcholine and methacholine on the intestine is well known (12-
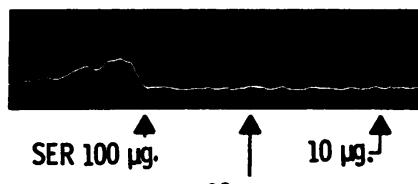

ACH $100 \mu \mathrm{gg}$.
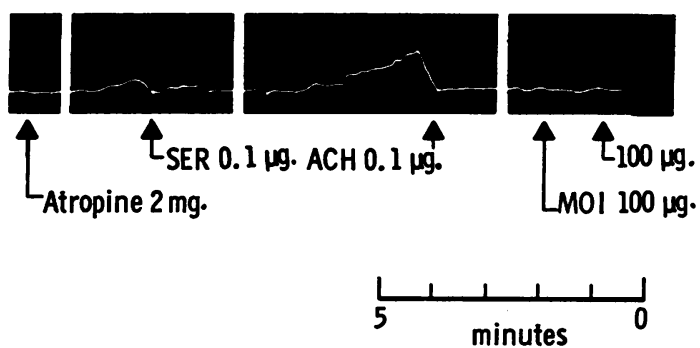

Fig. 12. Effect of Monoamine Oxidase Inhibitor (MOI) on Atropine Blockade (Dog No. 54)

Following two consecutive injections of $100 \mu \mathrm{g}$. of MOI, $2.0 \mathrm{mg}$. atropine retained its relative effect upon acetylcholine $(\mathrm{ACH})$ and serotonin (SER) responses. Read right to left. 


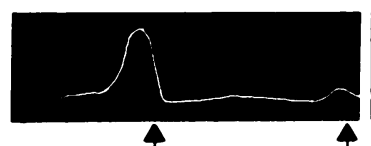

$\mathrm{ACH} 10 \mu \mathrm{gg}$.
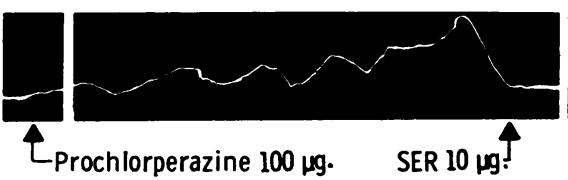

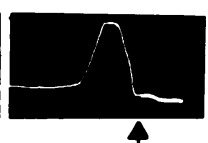

ACH 10 ug.

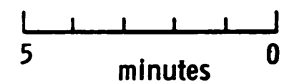

Fig. 13. Effect of Prochlorperazine (Dog No. 56)

Prochlorperazine $(100 \mu \mathrm{g}$.$) completely inhibited serotonin (SER) and did not$ affect acetylcholine (ACH). Read right to left.

14). In our studies the range of threshold dose of these two drugs was similar and approximates that derived from perfusion experiments (15); however, when these drugs are given intravenously, the average threshold dose range is about 1,000-fold greater (11).

Of interest is the finding that the characteristic responses to both these agents differ, the acetylcholine response being more rapid in onset and decline and the methacholine response lasting longer. The explanation of the longer methacholine response may be its slower hydrolysis by the tissue cholinesterase. The individual responses to each of these agents were reproducible over a period of eight to 10 hours, there being no tachyphylaxis or change in threshold dosage.

Study of the effect of acutely reducing the tissue cholinesterase upon the action of these agents through intra-arterial injection of DFP is limited by the reaction of the effector organ to large amounts of the anticholinesterase compound. When an amount is given sufficient to cause a greater than 90 per cent depression of cholinesterase, a sustained contraction which precludes re-injection is noted. Following this degree of cholinesterase suppression, Riker and Wescoe encountered similar spontaneous activity in a different neuroeffector system, chorda tympani nerve and the submaxillary gland of the cat (16). Further, they found that inordinate amounts of DFP were required to inactivate the remaining 10 per cent of cholinesterase. This may be attributed to the phenomenon described by Nachmansohn, Rothenberg and Feld (17) in which the reaction of cholinesterase and its inhibitor is shown to be stoichiometric but variable at different concentrations of the enzyme. At lower concentrations of cholinesterase, proportionately more DFP is required for inactivation, possibly 100,000 molecules of DFP being required for one of cholinesterase, whereas at higher concentrations, the ratio may be only 25 to 1 .

That approximately 80 per cent inhibition of cholinesterase is associated with only slight (10-

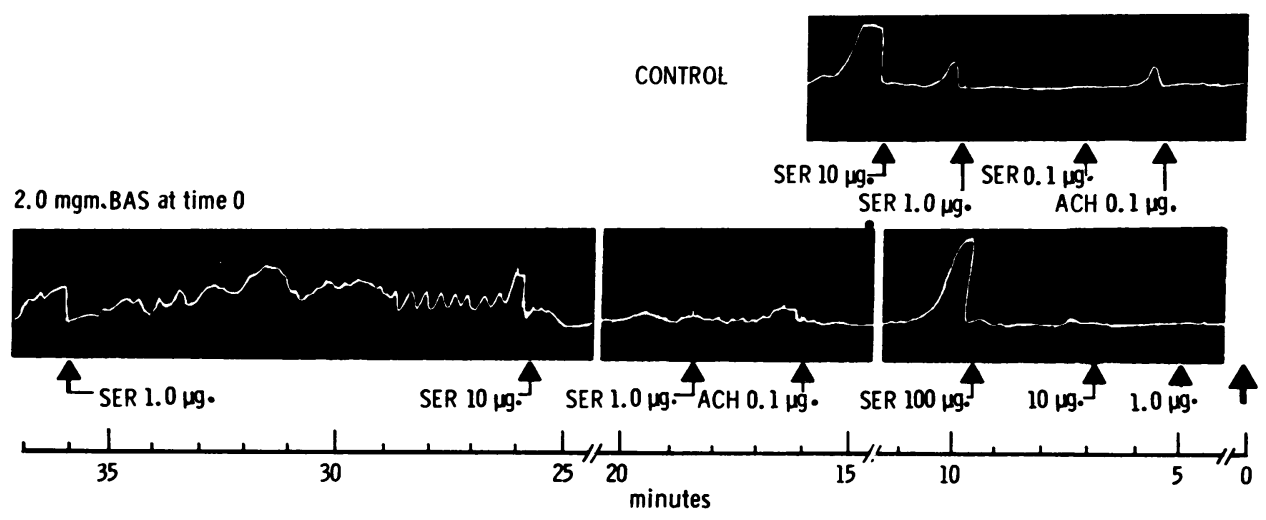

Fig. 14. Effect of Benzyl Analog of Serotonin (BAS)

(Dog No. 37)

Two mg. of BAS inhibited serotonin (SER) 100-fold for 30 minutes, but did not alter acetylcholine $(\mathrm{ACH})$ response. Read right to left. 
fold) alteration in threshold dosage seems surprising. However, Riker and Wescoe reported similar results in their experiments (16). Using DFP, they found that suppression of cholinesterase by at least 50 per cent was required to reduce threshold stimulus (frequency of electric shocks to the chorda tympani) and that the maximal alteration in threshold occurred only at 90 per cent suppression. When they administered supramaximal stimuli, the total response (volume of saliva) increased when cholinesterase was reduced 50 to 90 per cent; this increase was manifested principally as a prolongation of response after stimulation; the response during stimulation was altered slightly. These findings indicate that tissue cholinesterase occurs in a concentration which is far in excess of what is required for normal function.

These results in another parasympathetic-effector system are strikingly similar to those of the intestine. In the latter there was little change of threshold stimulus despite marked reduction in tissue cholinesterase and, analagous to the increased post-stimulus salivation for the submaxillary gland, there was prolongation of contraction in the intubated segment of the intestine (Figure 5). Further, Riker and Wescoe obtained the same relationship after DFP when the salivary gland was stimulated with intra-arterial injection of acetylcholine instead of by electrical shocking. These authors suggest that this augmented response is due to prolonged action of acetylcholine (or methacholine) at the myoneural junctions.

Serotonin appears to be as potent as acetylcholine in its contractile effect upon the intestinal musculature, the average threshold dose for each substance being the same and the magnitude and duration of response being comparable. There was no evidence for mutual potentiation with acetylcholine; mixtures of the two substances were at most only additive. Although the in vitro studies of Pick (9), using guinea pig ileum, suggested that serotonin enhanced the action of acetylcholine and related compounds, this finding is not confirmed by our work nor by that of Freyburger and associates (5).

That serotonin acts via a cholinergic pathway or mechanism seems unlikely for several reasons. First, although colon cholinesterase depression by
80 per cent or greater was associated with augmented response to both serotonin and acetylcholine, potentiation occurred only for the latter substance. Second, atropine was 100 times more potent in blocking acetylcholine than serotonin. Indeed, with lower doses of atropine, $1.0 \mathrm{mg}$. or less, serotonin response appeared to be augmented. Garven (18), using guinea pig ileum, showed that atropine had this same ratio of potency for inhibiting these two agents. Likewise, Gaddum and Hameed (1) found it only partially effective against the action of serotonin on the guinea pig ileum. However, Rocha e Silva, Valle and Picarelli (2), using a similar preparation, demonstrated that atropine was a potent inhibitor of both serotonin and acetylcholine. While Hendrix, Atkinson, Clifton and Ingelfinger (3) observed that atropine inhibited the action of serotonin upon the small intestine in man, Haverback and Davidson (4) could not confirm this finding. Since in both these experiments all substances were given intravenously, comparison with the in vitro and intra-arterial techniques is difficult.

That serotonin does not act via the autonomic ganglia is demonstrated by the failure of hexamethonium to block its response; indeed, an opposite effect may occur, since there was an augmented serotonin response in three of four instances in which it was given after hexamethonium. The reason for this augmentation, also suggested by Rocha e Silva and associates in their studies upon the guinea pig ileum (2), is unclear. It may be related to increased excitability of muscle fibers following ganglionic blockade, as was suggested by Feldberg (19). Possibly, large doses of methonium compounds stimulate the postsynaptic cells of the ganglia (20).

A striking observation in the experiments with hexamethonium was the failure of this agent, even in large dosage, to diminish the usual response to acetylcholine. Such diminution might have been expected since part of the action of acetylcholine upon smooth muscle of the intestine is mediated via the ganglion cells of the myenteric plexuses, and a large dose of hexamethonium may block acetylcholine at the neuroeffector junction (21). Perhaps a partial explanation, as suggested by Riker and Szreniawski (22), is that the predominant site for inhibition of acetylcholine by 
hexamethonium in the ganglion is not at the postsynaptic levels, but rather at the terminals of the presynaptic fibers.

Prochlorperazine and BAS completely block the spasmogenic action of serotonin upon the intestine and do not alter the acetylcholine response. This inhibitory effect of a phenothiazine has also been shown upon the rat colon, in vitro, by Benditt and Rowley (23). Such behavior might be expected, since the structure of serotonin is similar to epinephrine and norepinephrine, all three substances being destroyed by monoamine oxidase, and the phenothiazines possess sympatholytic properties (24). BAS probably exerts its effects by means of a specific competition with serotonin (25).

Monoamine oxidase, which exists in high concentration in the intestine (26), plays an important role in the metabolism of serotonin. Inhibition of this enzyme augments serotonin response. The kinetics of this interaction may be analogous to that for acetylcholine and cholinesterase, since inhibition of cholinesterase is associated with an augmentation of acetylcholine effect. This interaction of serotonin and monoamine oxidase, which probably occurs at a significant rate in the intestine, may further indicate that serotonin plays a role in the regulation of motility of this organ.

Although it seems clear from these studies that exogenously administered serotonin does not act by way of a cholinergic pathway in the intact animal, it has been amply established by Bülbring and Lin (27) that this agent acts as a modulator of the cholinergic system by reducing the threshold of the presso-receptors in the gut wall. Possibly, a ganglionic blocking effect of serotonin in our intact preparation may have prevented its potentiation of acetylcholine at the neuroeffector site (28).

\section{SUMMARY}

1. An in vivo intra-arterial injection technique for the study of the effect of drugs upon the smooth muscle of the dog colon is described. Using this technique, the threshold dosage for acetylcholine and methacholine has ranged from 0.001 to $0.1 \mu \mathrm{g}$, and 0.001 to $1.0 \mu \mathrm{g}$., respectively.

2. Utilizing di-isopropylfluorophosphate, acute reduction of bowel cholinesterase ( 43 to 97 per cent) was achieved. This alteration was associ- ated uniformly with augmentation of response to both acetylcholine and methacholine; however, at least 80 per cent inhibition was necessary to alter the threshold dose.

3. The action of 5-hydroxytryptamine (serotonin) and acetylcholine upon the colon of intact, anesthetized dogs was compared. The average threshold dose to induce contraction was the same for each substance.

4. Atropine was ineffective in blocking serotonin response as compared with acetylcholine, and inhibition of tissue cholinesterase failed to potentiate serotonin effect.

5. Although hexamethonium blocked neither acetylcholine nor serotonin response, mediation of action of these substances via autonomic ganglia is not excluded, since hexamethonium may act at the presynaptic level.

6. Effect of serotonin was enhanced by inhibition of monoamine oxidase and was blocked by both its benzyl analog and a phenothiazine derivative, prochlorperazine.

7. These results suggest that when serotonin is administered intra-arterially to an intact colon, it does not act via a cholinergic pathway; however, they do not negate previous evidence that this substance may be a modulator of the cholinergic system.

\section{ACKNOWLEDGMENT}

The authors are indebted to Drs. William F. Nickel, Jr., and David S. Speer, of The New York HospitalCornell Medical Center, for their technical assistance and gratefully acknowledge the interest and help of Drs. Walter F. Riker and Jay Roberts of the Cornell University Medical College.

\section{REFERENCES}

1. Gaddum, J. H., and Hameed, K. A. Drugs which antagonize 5-hydroxytryptamine. Brit. J. Pharmacol. 1954, 9, 240.

2. Rocha e Silva, M., Valle, J. R., and Picarelli, P. A pharmacological analysis of the mode of action of serotonin (5-hydroxytryptamine) upon the guinea-pig ileum. Brit. J. Pharmacol. 1953, 8, 378.

3. Hendrix, T. R., Atkinson, M., Clifton, J. A., and Ingelfinger, F. J. The effect of 5-hydroxytryptamine on intestinal motor function in man. Amer. J. Med. 1957, 23, 886.

4. Haverback, B. J., and Davidson, J. D. Serotonin and the gastrointestinal tract. Gastroenterology $1958,35,570$. 
5. Freyburger, W. A., Graham, B. E., Rapport, M. M., Seay, P. H., Govier, W. M., Swoap, O. F., and Vander Brook, M. J. The pharmacology of 5-hydroxytryptamine (serotonin). J. Pharmacol. exp. Ther. 1952, 105, 80.

6. Sjoerdsma, A., Weissbach, H., and Udenfriend, S. A clinical, physiologic and biochemical study of patients with malignant carcinoid (argentaffinoma). Amer. J. Med. 1956, 20, 520.

7. Thorson, A. H. Studies on carcinoid disease. Acta med. scand. 1958, 161, Suppl. 334.

8. Rapport, M. M., and Koelle, G. B. The action of antihistaminics and atropine in blocking the spasmogenic activity of serotonin on the guinea pig ileum. Arch. int. Pharmacodyn. 1953, 92, 464.

9. Pick, E. P. Potentiating action of serotonin on choline compounds. J. Mt Sinai Hosp. 1957, 24, 1104.

10. Jaques, R., Bein, H. J., and Meier, R. 5-Hydroxytryptamine antagonists, with special reference to the importance of sympathomimetic amines and isopropyl-noradrenaline. Helv. physiol. pharmacol. Acta 1956, 14, 269.

11. Sleisenger, M. H., Lewis, C. M., Pert, J. H., Roseman, D. R., Nickel, W. F., Jr., and Almy, T. P. Use of parasympathetic stimulation in the production of bloody diarrhea in dogs, with reference to the role of red cell and colon cholinesterase. Gastroenterology 1958, 34, 582.

12. Molitor, $\mathrm{H}$. A comparative study of the effects of five choline compounds used in therapeutics: acetylcholine chloride, acetyl betamethylcholine chloride, carbaminoyl choline, ethyl ether betamethylcholine chloride, carbaminoyl betamethylcholine chloride. J. Pharmacol. exp. Ther. 1936, 58, 337.

13. Koppanyi, T. Acetylcholine as a pharmacological agent. Bull. Johns Hopk. Hosp. 1948, 83, 532.

14. Wolff, L. H. Effect of certain parenterally administered drugs on the colon of the dog. Amer. J. dig. Dis. 1939, 6, 243.

15. Bean, J. W., and Sidky, M. M. Intestinal blood flow as influenced by vascular and motor reactions to acetylcholine and carbon dioxide. Amer. J. Physiol. 1958, 194, 512.
16. Riker, W. F., and Wescoe, W. C. The relationship between cholinesterase inhibition and function in a neuro-effector system. J. Pharmacol. exp. Ther. $1949,95,515$.

17. Nachmansohn, D., Rothenberg, M. A., and Feld, E. A. The in vitro reversibility of cholinesterase inhibition by diisopropyl fluorophosphate (DFP). Arch. Biochem. 1947, 14, 197.

18. Garven, J. D. Pharmacological blocking actions of atropine and certain atropine-like compounds. J. Pharm. (Lond.) 1956, 8, 256.

19. Feldberg, W. Effects of ganglion-blocking substances on the small intestine. J. Physiol. 1951, $113,483$.

20. Perry, W. L. M., and Reinert, H. The effects of preganglionic denervation on the reactions of ganglion cells. J. Physiol. (Lond.) 1954, 126, 101.

21. Paton, W. D. M. Transmission and block in autonomic ganglia. Pharmacol. Rev. 1954, 6, 59.

22. Riker, W. K., and Szreniawski, Z. The pharmacological reactivity of presynaptic nerve terminals in a sympathetic ganglion. J. Pharmacol. exp. Ther. 1959, 126, 233.

23. Benditt, E. P., and Rowley, D. A. Antagonism of 5-hydroxtyryptamine by chlorpromazine. Science 1956, 123, 24.

24. Huidobro, F. Some pharmacological properties of chloro-3 (dimethyl-amine-3'propyl) 10-phenothiazine or 4.560 R.P. Arch. int. Pharmacodyn. 1954, 98, 308.

25. Woolley, D. W. Antimetabolites. Science 1959, 129, 615.

26. Blaschko, H. Amine oxidase and amine metabolism. Pharmacol. Rev. 1952, 4, 415.

27. Bülbring, E., and Lin, R. C. Y. The effect of intraluminal application of 5-hydroxytryptamine and 5-hydroxytryptophan on peristalsis; the local production of 5-ht and its release in relation to intraluminal pressure and propulsive activity. J. Physiol. (Lond.) 1958, 140, 381.

28. Bülbring, E., and Crema, A. Observations concerning the action of 5-hydroxytryptamine on the peristaltic reflex. Brit. J. Pharmacol. 1958, 13, 444. 